\title{
Crystal modifications and dissolution rate of piroxicam
}

\author{
LIM YEE LYN ${ }^{1}$ \\ HUAN WEN SZE ${ }^{1}$ \\ ADHIYAMAN RAJENDRAN \\ GORAJANA ADINARAYANA ${ }^{1, *}$ \\ KAMAL DUA ${ }^{1}$ \\ SANJAY GARG ${ }^{2}$ \\ ${ }^{1}$ School of Pharmacy and Health \\ Sciences, International Medical \\ University, Bukit Jalil, Kuala \\ Lumpur, Malaysia \\ 2 AnQual Laboratories, School of \\ Pharmacy, University of Auckland \\ Auckland, New Zealand
}

\begin{abstract}
Piroxicam is a nonsteroidal anti-inflammatory drug with low aqueous solubility which exhibits polymorphism. The present study was carried out to develop polymorphs of piroxicam with enhanced solubility and dissolution rate by the crystal modification technique using different solvent mixtures prepared with PEG 4000 and PVP K30. Physicochemical characteristics of the modified crystal forms of piroxicam were investigated by X-ray powder diffractometry, FT-IR spectrophotometry and differential scanning calorimetry. Dissolution and solubility profiles of each modified crystal form were studied and compared with pure piroxicam. Solvent evaporation method (method I) produced both needle and cubic shaped crystals. Slow crystallization from ethanol with addition of PEG 4000 or PVP K30 at room temperature (method II) produced cubic crystal forms. Needle forms produced by method I improved dissolution but not solubility. Cubic crystals produced by method I had a dissolution profile similar to that of untreated piroxicam but showed better solubility than untreated piroxicam. Cubic shaped crystals produced by method II showed improved dissolution, without a significant change in solubility. Based on the XRPD results, modified piroxicam crystals obtained by method I from acetone/benzene were cube shaped, which correlates well with the FTIR spectrum; modified needle forms obtained from ethanol/methanol and ethanol/acetone showed a slight shift of FTIR peak that may be attributed to differences in the internal structure or conformation.
\end{abstract}

Keywords: piroxicam, polymorphism, crystallization, polymer, dissolution

Piroxicam, an oxicam derivative, is a nonsteroidal anti-inflammatory drug (NSAID). It has anti-inflammatory, analgesic, and antipyretic properties. Piroxicam can be taken orally to treat inflammatory diseases such as rheumatoid arthritis and osteoarthritis, musculoskeletal disorders or postoperative pain (1). Chemically, piroxicam is 4-hydroxy-2-

\footnotetext{
* Correspondence; e-mail: adinarayana_gorajana@imu.edu.my
} 
-methyl- $\mathrm{N}$-(2-pyridyl)-2H-1,2-benzothiazine-3-carboxamide-1,1-dioxide. The molecular structure of piroxicam is shown in Fig. 1 . It has the molecular formula $\mathrm{C}_{15} \mathrm{H}_{13} \mathrm{~N}_{3} \mathrm{O}_{4} \mathrm{~S}$ and relative molecular mass 331.3. Piroxicam is acidic, sparingly soluble in water, slightly soluble in alcohol and alkaline aqueous solutions and soluble in methylene chloride (1). Piroxicam belongs to the biopharmaceutical classification system class II drugs of low aqueous solubility and high permeability (2). After oral administration, it takes about 3 to 5 hours for piroxicam to reach its peak plasma concentration (1). This shows that there is poor absorption after oral administration. Drugs with limited aqueous solubility have slow dissolution in biological fluid; low and erratic bioavailability leads to sub-optimal efficacy in patients. Crystal engineering is an approach that may improve solubility, dissolution rate and bioavailability of crystalline drugs.

Polymorphism means that a chemical substance can exist in different crystal forms.<smiles>CN1C(C(=O)Nc2ccccn2)=C(O)c2ccccc2S1(=O)=O</smiles>

Fig. 1. Chemical structure of piroxicam.

A crystalline drug can have different polymorphic forms if crystallized under different conditions. Polymorphs can have different physical properties, such as solubility and dissolution characteristics. Crystals of higher free energy will have higher solubility. This is because molecules in crystals with high energy have weaker solid-solid interactions and higher affinity for the solvent in the surroundings compared to crystals with lower energy (3).

In our previous studies, the dissolution rate and solubility of dipyridamole were tested using solvents such as methanol, benzene, acetonitrile with the addition of polymers such as Tween-80, Povidone K30 and PEG 4000 into the solvent for crystal modification (1). It was found that the newly developed crystals had a higher dissolution rate than the pure drug. According to other published studies, polymers such as polyethylene glycol (PEG) and polyvinylpyrrolidone (PVP) have been used as excipients for the purpose of improving the dissolution rate of many poorly water-soluble drugs such as NSAIDs $(4,5)$.

The present study has been designed to improve the solubility and dissolution rate of piroxicam by the crystal modification technique using different solvent mixtures and addition of different polymers into the solvent system.

\section{EXPERIMENTAL}

\section{Materials}

Piroxicam was obtained from CCM Pharmaceuticals Malaysia Berhad (Malaysia). Solvents used were of analytical grade and were obtained from Merck, Germany. The polymers, polyethylene glycol (PEG) 4000 and Povidone (PVP) K30, were purchased from Sigma-Aldrich Chemie GmbH (Germany) and Sigma-Aldrich (USA), respectively. 


\section{Development of piroxicam crystals}

Modified crystal forms of piroxicam were prepared by the solvent evaporation and slow crystallization method. In the solvent evaporation method, piroxicam was recrystallized from solvent mixtures made up of two solvents at a ratio of 1:1. Various solvent mixtures used were ethanol/methanol, ethanol/acetone, acetone/benzene and chloroform/acetone. In the slow crystallization method, ethanol was used as solvent and the polymers employed were PEG 4000 and PVP K30 at a concentration of 2 and $5 \%$.

Method I. - For the solvent evaporation method, $0.75 \mathrm{~g}$ of piroxicam was dissolved in $50 \mathrm{~mL}$ of solvent mixture ( $25 \mathrm{~mL}$ of each solvent). The solution was heated till the drug dissolved. The solution was cooled to room temperature until the solvent evaporated completely. Crystals formed were dried under vacuum at room temperature and stored in a desiccator for further use (6).

Method II. - For the slow crystallisation method (method II), $0.75 \mathrm{~g}$ of piroxicam was dissolved in $50 \mathrm{~mL}$ of ethanol by heating and stirring continued until the whole drug dissolved. The drug solution was filtered to remove impurities and concentrated by heating. An equal amount of polymer was rapidly added into the concentrated solution under mild stirring for 2 minutes at room temperature $\left(23-24^{\circ} \mathrm{C}\right)$. The resultant crystals were washed, recovered by vacuum filtration and then stored in a desiccator for further use.

\section{Characterization of piroxicam crystals}

Powder X-ray diffraction (XRPD). - Powder X-ray powder diffraction study was performed using a D8 Advance Bruker AXS (Germany). Samples were placed in a sample holder and scanned in the diffraction angle range (20) between 2 and $25^{\circ}$. Radiation was generated by a Cu K $\mathrm{K}_{\alpha}$ filter at a wavelength of $1.5406 \AA$. Diffractograms were run at $40 \mathrm{kV}$ and $40 \mathrm{~mA}$ current.

Scanning electron microscopy (SEM). - Samples were mounted on metal stubs using double adhesive tape and were coated under vacuum with platinum at 5-10 mA, $1.0 \mathrm{kV}$ using a Polaron SC 7640 sputter coater in an argon atmosphere prior to observation. Electron micrographs of the samples were obtained using a scanning electron microscope (Phillips XL30S FEG, USA).

Melting point determination. - Melting point of piroxicam and its modified forms was determined by the capillary method.

Differential scanning calorimetry (DSC). - Thermal analysis was performed on samples using a thermal analysis system (Mettler-Toledo DSC 823e, Switzerland). Sample (5 mg) was weighed into an aluminium pan and sealed. Thermograms of samples were obtained at a scanning rate of $10{ }^{\circ} \mathrm{C} \mathrm{min}^{-1}$ over a temperature range of $30-275{ }^{\circ} \mathrm{C}$ under a nitrogen atmosphere. A similar empty pan was used as reference.

Fourier transform infrared (FTIR) spectroscopy. - The sample (1 mg) was compressed into a disc with $100 \mathrm{mg}$ dried potassium bromide. Discs were examined using an FTIR spectrophotometer (Shimadzu, FTIR-8400S, Japan) and a spectrum between $400-4000 \mathrm{~cm}^{-1}$ was recorded. 
Solubility studies. - Solubility studies of piroxicam and its modified crystal forms were carried out in buffer $\mathrm{pH}$ 1.2. Five $\mathrm{mg}$ of each sample was weighed into vials containing $15 \mathrm{~mL}$ of buffer $\mathrm{pH}$ 1.2. The vials were shaken at $100 \mathrm{rpm}$ at $25^{\circ} \mathrm{C}$ for $24 \mathrm{~h}$. Samples were analyzed for piroxicam concentration at $333 \mathrm{~nm}$ using a UV spectrophotometer (Jasco, V-530, Japan).

Dissolution studies. - Dissolution studies of piroxicam and its modified forms were conducted using a USP type Apparatus II (paddle apparatus) (SR8 PLUS, Hanson Research, Canada) (15). Twenty mg of sample was added to $900 \mathrm{~mL}$ of buffer $\mathrm{pH} 1.2$ at $37 \pm 5{ }^{\circ} \mathrm{C}$. Paddle rotation speed was maintained at $50 \mathrm{rpm}$. In all experiments, $5 \mathrm{~mL}$ of dissolution sample was withdrawn at selected time intervals and replaced with an equal volume of fresh medium of $37 \pm 0.5^{\circ} \mathrm{C}$. Samples were assayed at $333 \mathrm{~nm}$.

\section{RESULTS AND DISCUSSION}

XRPD patterns of different samples of piroxicam crystallized by method I are shown in Fig. 2. According to the diffraction patterns observed, piroxicam crystallized from acetone/benzene in cube shaped crystals whereas crystallization from ethanol/methanol, ethanol/acetone and chloroform/acetone mixtures yielded needle shaped crystals (7).

The diffraction pattern obtained for modified crystal forms of piroxicam obtained using method II are also shown in Fig. 2. The diffraction pattern of recrystallized piroxicam corresponds to cube shaped crystals. Absence of PEG 4000 and PVP K30 amorphous peaks in the XRPD spectra was observed.

Morphology of crystals obtained from different solvent mixtures is shown in Fig. 3. All modified forms obtained by method I have different morphology compared to untreated piroxicam (Fig. 3a). Piroxicam appears to have an uneven surface, which may be due to agglomeration or aggregation of piroxicam powder. Modified forms obtained by method I were needle-shaped with a smooth surface, except for piroxicam crystallized from the acetone/benzene mixture (Fig. 3d) which had a rough and uneven surface. Crystal habit can be affected during the crystallization process by factors such as polarity of the crystallization solvent used (8).

According to Mihalić et al. (9), piroxicam appears to be in cube shaped crystal and in needle forms when it is precipitated by fast cooling. Similar results were obtained in the present study; scanning electron micrographs of piroxicam recrystallized using method II are also shown in Fig. 3. Recrystallised piroxicam had different morphology from that of untreated piroxicam (Fig. 3a). All the modified crystal forms of piroxicam obtained by method II majorly comprised cube shaped crystals having flat surfaces and straight edges along with some needle recrystallized piroxicam.

Water soluble polymers, PEG 4000 and PVP K30, were added during the recrystallization process in method II. From Figs. 3f-i it follows that piroxicam recrystallized by method II was precipitated as a cube shaped crystal. This indicates that the polymers were laid on the surface of the cubic crystal instead of being incorporated into it. It was difficult to distinguish the polymer from piroxicam crystals and their size using the scanning electron microscope. The presence of the polymer cannot be visualized using scanning electron microscope. Polymer probably affects the crystal size which forther influ- 
Fig. 2. Powder X-ray diffraction of piroxicam crystallized from: a) ethanol/methanol, b) ethanol/acetone, c) acetone/benzene, d) chloroform/acetone; piroxicam recrystallized from ethanol using e) PEG $40002 \%$, f) PEG $40005 \%$, g) PVP K30 2 $\%$ and h) PVP K30 $5 \%$.

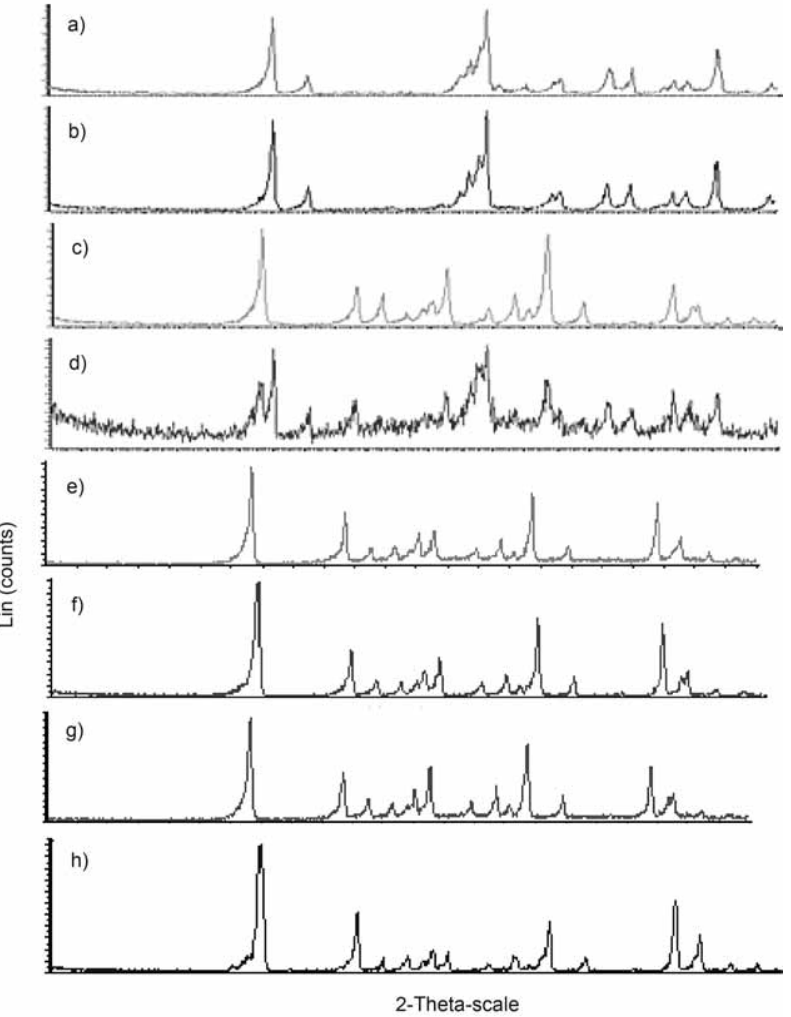

ences the physical properties such as dissolution and solubility. Thus the particle size analysis of piroxicam recrystallized from the different polymers at different concentrations can be investigated.

\section{Melting point}

According to the literature, piroxicam exists in two inter-convertible crystal polymorphs where the needle form has lower melting point of $196-198{ }^{\circ} \mathrm{C}$ and the cube shaped crystal has higher melting point of $199-201{ }^{\circ} \mathrm{C}$.

Modified crystal forms of piroxicam obtained by method II had melting points ranging from $200-203{ }^{\circ} \mathrm{C}$. This data corresponds well with the XRPD data, which shows that piroxicam and all the modified crystal forms of piroxicam are cube shaped crystals. Modified forms of piroxicam produced by method I (ethanol/methanol and chloroform/acetone) had a lower melting point than untreated piroxicam, suggesting that they are in needle form. 


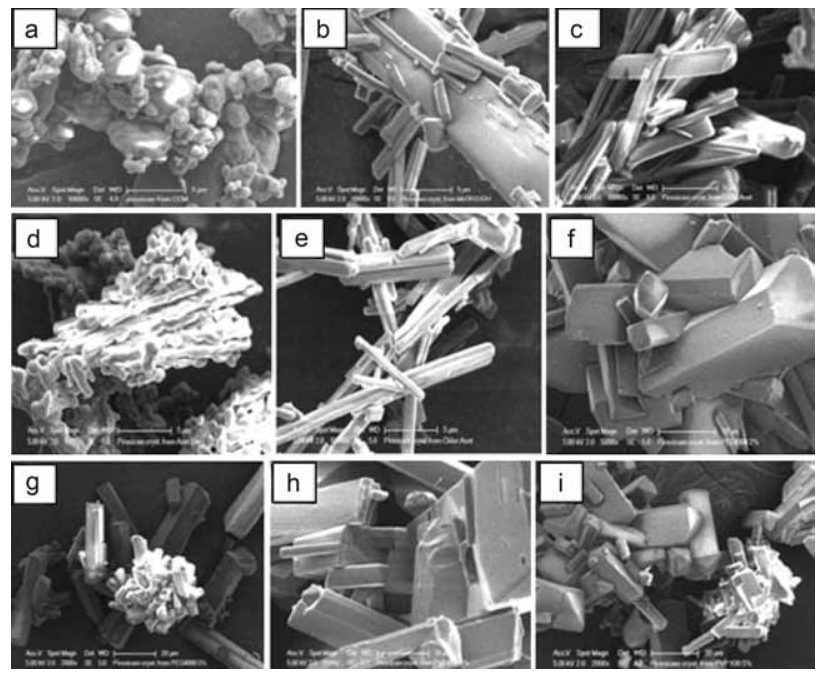

Fig. 3. Scanning electron micrographs of: a) untreated piroxicam; piroxicam crystallized from b) ethanol/methanol; c) ethanol/acetone; d) acetone/benzene; e) chloroform/acetone; f) piroxicam recrystallized from ethanol solvent using PEG $40002 \%$; g) PEG $40005 \%$; h) PVP K30 2 \%; i) PVP K30 $5 \%$.

DSC

DSC thermograms of piroxicam and its modified forms obtained by method I are shown in Fig. 4. The thermograms are similar. Piroxicam with a melting peak of $201.89^{\circ} \mathrm{C}$ is in the cube shaped crystal. Piroxicam crystallized from ethanol/methanol, ethanol/ acetone and chloroform/acetone had a slightly lower melting point compared to piroxicam, which suggests that they are in needle form. DSC thermogram of piroxicam crystallized from ethanol/acetone and chloroform/acetone showed that there may be a precipitation of a stable form with higher melting point from a form with a lower melting point.

The DSC thermograms of all modified crystal forms obtained by method II were identical with that of untreated piroxicam. There was a prominent endothermic peak in DSC thermograms at about $200-203{ }^{\circ} \mathrm{C}$ for all recrystallized piroxicam and untreated piroxicam samples, which corresponds to the melting point of the drug. There are no endotherm peaks of PEG 4000 and PVP K30 in the DSC thermograms. This may indicate that the polymers were not incorporated during crystallization.

\section{FTIR}

Based on the literature, piroxicam exists in two interconvertible crystal polymorph needle forms that have $-\mathrm{NH}$ and $-\mathrm{OH}$ stretching bonds at $3385 \mathrm{~cm}^{-1}$ and a cube shaped crystal with a stretching bond at $3330 \mathrm{~cm}^{-1}$. There are only small differences in the fingerprint region, allowing comparison of crystal forms to be done in the region 2500 to $4000 \mathrm{~cm}^{-1}$. Fig. 5a shows an absorption band at $3338 \mathrm{~cm}^{-1}$ that indicates the cube shaped crystal of piroxicam (9). 
Fig. 4. Differential scanning calorimetric thermographs of: a) untreated piroxicam; b) piroxicam crystallized from ethanol/methanol; c) ethanol/acetone; d) acetone/benzene; e) chloroform/acetone; piroxicam recrystallized from ethanol solvent using: f) PEG $40002 \%$; g) PEG $40005 \%$; h) PVP K30 $2 \%$; i) PVP K30 $5 \%$.

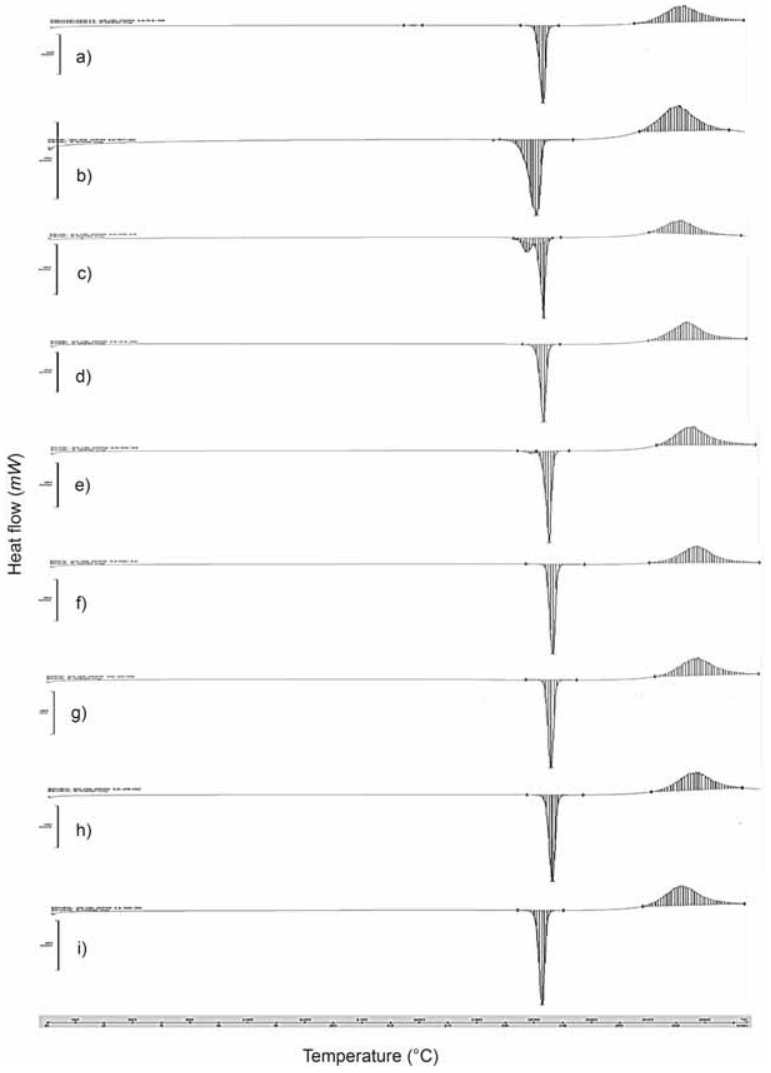

Based on the XRPD results, modified piroxicam from acetone/benzene is in the cube shaped crystal. From the FTIR spectrum in Fig 5c, it has a peak at $3338 \mathrm{~cm}^{-1}$, which correlates well with the cube shaped crystal in the literature (9). Modified needle forms obtained from ethanol/methanol and ethanol/acetone had a peak at $3393 \mathrm{~cm}^{-1}$. There is a slight shift in the peak for needle crystals compared to literature data (9). From XRPD, piroxicam crystallized from chloroform/acetone is needle-shaped and in the FTIR spectrum peaks are observed at 3393 and $3338 \mathrm{~cm}^{-1}$, but shows only a peak at $3393 \mathrm{~cm}^{-1}$ which may possibly be attributed to the difference in the internal structure or conformation.

For piroxicam recrystallized from method II, all the spectra are identical to the untreated form of piroxicam. It is shown that all the samples have a sharp absorption at $3338 \mathrm{~cm}^{-1}$. This indicates that recrystallized piroxicam is present as a cube shaped crystal. These IR spectra correspond well to the XRPD, SEM, melting points and DSC data.

FTIR spectroscopic analysis can be used to analyze the possible interaction between the drug and polymers. Figs. $5 \mathrm{f}-\mathrm{i}$ show the IR-spectra of recrystallized piroxicam using method II. Absence of PEG 4000 and PVP K30 peaks was observed in the spectra of all samples. From the chemical structure of these polymers, hydroxyl groups of PEG 4000 and each pyrrolidone moiety of PVP exhibiting two groups $(>\mathrm{N}-$ and $\mathrm{C}=\mathrm{O})$ can be po- 


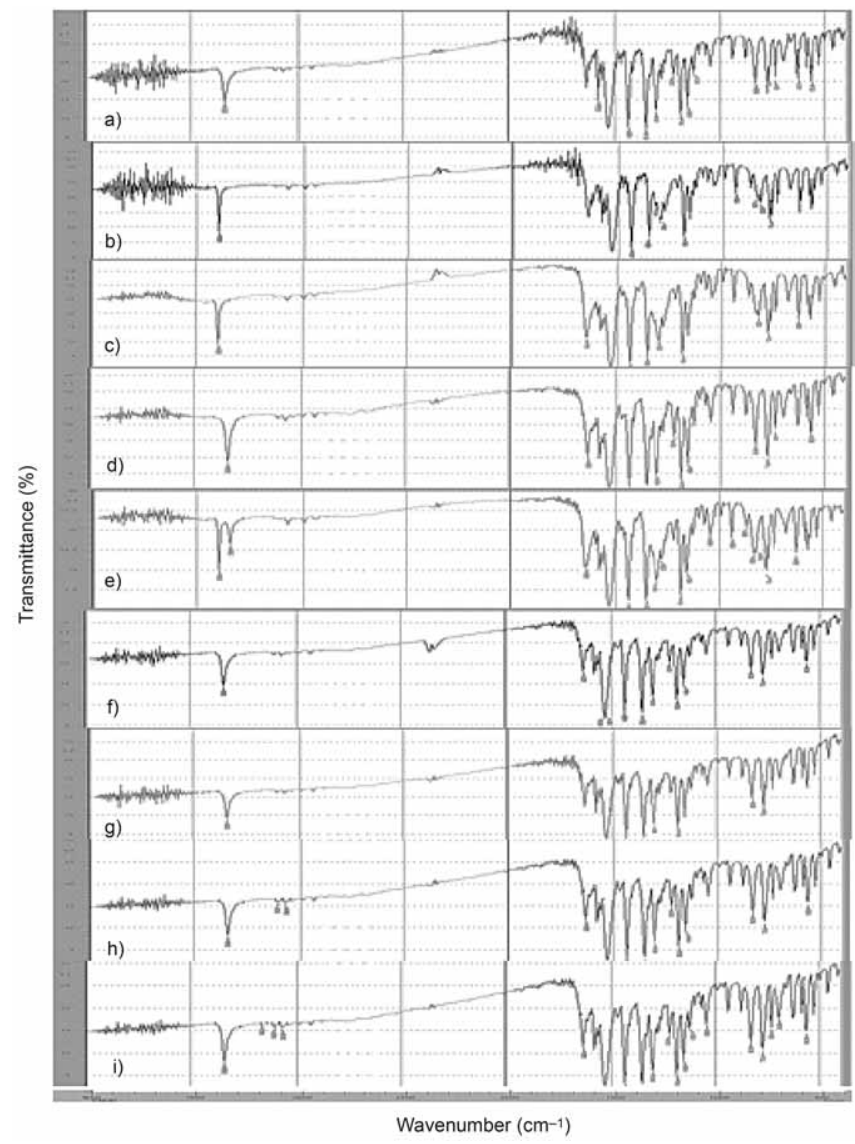

Fig. 5. FTIR spectra of: a) untreated piroxicam; b) piroxicam crystallized from ethanol/methanol; c) ethanol/acetone; d) acetone/benzene; e) chloroform/acetone; piroxicam recrystallized from ethanol solvent using: f) PEG 40002 \%; g) PEG $40005 \%$; h) PVP K30 2 \%; i) PVP K30 5 \%.

tentially hydrogen bonded with the amide $(\mathrm{N}-\mathrm{H})$ group or protonated pyridine $\mathrm{N}$ atom of piroxicam (10). Theoretically, there can be a chemical interaction between the drug and polymers. However, the spectra of all samples were identical and do not show any alteration in absorption bands. Therefore, these results suggest that there was no interaction between piroxicam and polymers during crystallization.

\section{Solubility and dissolution studies}

Dissolution is primarily dependent on the solubility of a drug substance and a compound with aqueous solubility lower than $0.1 \mathrm{mg} \mathrm{mL}^{-1}$ often exerts dissolution limitations to absorption (2). Piroxicam is practically insoluble and shows two $\mathrm{p} K_{\mathrm{a}}$ values $\left(\mathrm{p} K_{\mathrm{a} 1}=1.86\right.$ and $\left.\mathrm{p} K_{\mathrm{a} 2}=5.46\right)(2)$. 
Table I. Melting points, solubility after three hours and twenty-four hours for untreated piroxicam and its modified forms prepared using different solvent mixtures and solvent systems

\begin{tabular}{lcrc}
\hline \multirow{2}{*}{ Type of crystals } & \multirow{2}{*}{$\begin{array}{c}\text { Melting points } \\
\left({ }^{\circ} \mathrm{C}\right)\end{array}$} & \multicolumn{2}{c}{ Solubility $\left(\mu \mathrm{g} \mathrm{mL}^{-1}\right)$} \\
\cline { 3 - 4 } & $200-203$ & 97.732 & 88.757 \\
\hline Untreated piroxicam & & & \\
Piroxicam crystallized from & & & 24 hours \\
Ethanol/methanol & $197-199$ & 134.911 & 68.935 \\
Ethanol/acetone & $200-203$ & 134.615 & 70.118 \\
Acetone/benzene & $200-203$ & 96.351 & 107.990 \\
Chloroform/acetone & $199-201$ & 125.542 & 75.345 \\
Ethanol/PEG4000 (2 \%) & $201-204$ & 91.519 & 136.031 \\
Ethanol/PEG4000 (5 \%) & $202-205$ & 95.069 & 143.527 \\
Ethanol/PVP K30 (2 \%) & $200-203$ & 92.110 & 94.014 \\
Ethanol/PVP K30 (5 \%) & $200-203$ & 90.927 & 114.310 \\
\hline
\end{tabular}

Solubility test on piroxicam and its modified forms was carried after 3 and 24 hours. From Table I, untreated piroxicam has higher solubility after 3 hours compared to 24 hours. This is also observed in all the modified forms of piroxicam except for piroxicam crystallized by method I using an acetone/benzene mixture. Reduction in solubility from 3 to 24 hours may be due to the change in the form of the crystal in the medium. A metastable form can convert to a more stable form leading to reduced solubility. Piroxicam crystallized from acetone/benzene had slightly lower solubility after 3 hours but showed improvement in solubility at 24 hours. This may be due to the stable form, which is resistant to conversion to another form.

Dissolution profile of piroxicam and its modified forms is shown in Figs. 6a and b. The 3-hour solubility profile of modified forms of piroxicam is reflected in dissolution results where all samples have a better dissolution profile than untreated piroxicam except for piroxicam crystallized from the acetone/benzene mixture using method I. The most prominent improvement in dissolution was obtained using modified crystal forms of piroxicam oftained by method II using ethanol as the solvent with $5 \%$ PVP K30. It showed about 2 -fold increase in dissolution; this means that $99.8 \%$ of the drug dissolved compared to $56.8 \%$ of untreated piroxicam dissolved after 3 hours. There was also an increase in dissolution with increasing polymer concentration. At higher polymer concentration, which is $5 \%$ for PEG 4000 and PVP K30, the dissolution profile of recrystallized piroxicam using ethanol solvent at room temperature increased from 85.7 to $93.5 \%$ and 94.6 to $99.8 \%$, respectively.

Needle forms produced by method I and cube shaped crystals obtained by method II showed improved dissolution but not solubility. Cubic crystals produced by method I havea dissolution profile similar to that of untreated piroxicam and better solubility.

Dissolution results also contradict the solubility results in 24 hours. Samples with good dissolution have poor solubility after 24 hours and vice versa. This phenomenon could be attributed to the negative nature of Gibbs free energy changes and spontaneity of the process $(12,14)$. Therefore, all the modified crystal forms of piroxicam with good 

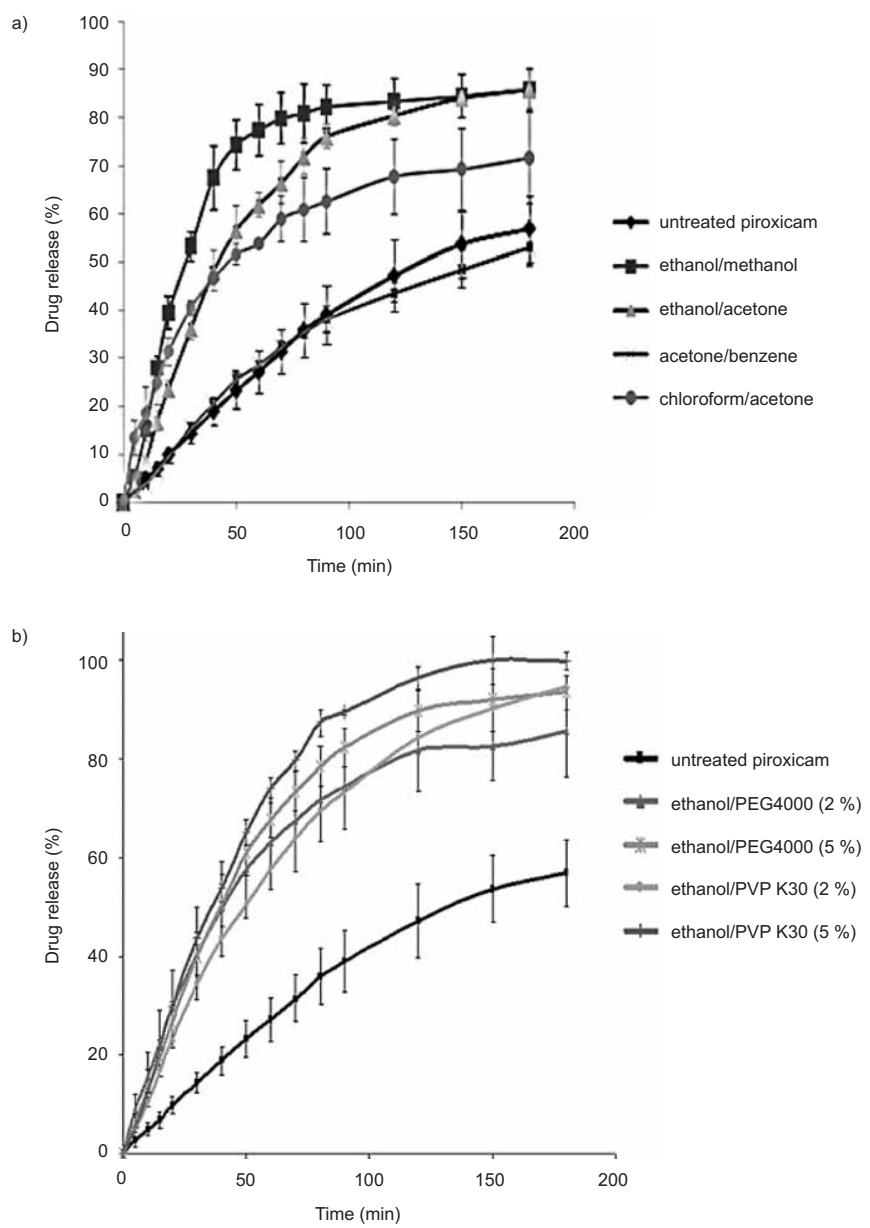

Fig. 6. Dissolution profile of: a) untreated piroxicam and modified forms of piroxicam crystallized from various solvent mixtures, b) modified crystals crystallized by the slow recrystallization method with incorporation of polymer. Mean \pm SD, $n=3$.

dissolution have low solubility after 24 hours due to the transformation to a stable form with low solubility, except for piroxicam crystallized from acetone/benzene using method I.

Piroxicam is almost insoluble in water and hence remains floating on the surface of the dissolution medium due to poor contact with the medium thereby resulting in a poor dissolution profile. Difference in the dissolution and solubility profile of the modified piroxicam can be due to the difference in crystal structure. Solvents with varying polarities and desolvation process affect crystal formation, leading to different morphologies and properties of crystals obtained from different solvent mixtures (3).

Crystallization process is also affected by the choice of additives $(4,8,11,12)$. Addition of PEG 4000 and PVP K30 during recrystallization influenced the dissolution rate. 
According to physicochemical characterization, piroxicam and piroxicam recrystallized using method II are in cube shaped crystals. However, recrystallized piroxicam displayed a better dissolution profile than the untreated form of piroxicam. The differences are due to the use of water-soluble hydrophilic polymers $(4,8)$ forming a hydrophilic film on the surface of drug crystals, increasing the drug wettability and preventing drug aggregation, changing the crystallinity of piroxicam and giving rise to a form with a better dissolution rate $(4,11,10,13)$. The presence of additives during the crystallization process might also cause a defect in the crystal structure and the crystal would become thermodynamically unstable and hence dissolve faster.

\section{CONCLUSIONS}

In conclusion, modification of piroxicam by evaporation from different solvent mixtures and incorporation of a polymer resulted in formation of different crystal forms. Needle forms produced from solvent evaporation had improved dissolution but not solubility while cube shaped crystals produced from solvent evaporation had a similar dissolution profile and better solubility than untreated piroxicam. Cube shaped crystals produced by the slow crystallization method with addition of a polymer had improved dissolution but not solubility. For future studies, single crystallographic studies can be carried out to further examine the single crystal structure.

\section{REFERENCES}

1. A. Rajendarn and S. K. Basu, Crystal modification of dipyridamole using different solvents and crystallization conditions, Int. J. Pharm. 321 (2006) 27-34; DOI: 10.1016/J.IJPHARM.2006.04.021.

2. N. Blagden, M. de Matas, P. T. Gavan and P. York, Crystal engineering of active pharmaceutical ingredients to improve solubility and dissolution rates, Adv. Drug Del. Rev. 59 (2007) 617-630; DOI: 10.1016/J.ADDR.2007.05.011.

3. S. R. Byrn, R. R. Pfeiffer, G. Stephenson, D. J. W. Grant and W. B. Gleason, Solid state pharmaceutical chemistry, Chem. Mater. 6 (1994) 1148; DOI: 10.1021/cm00044a013.

4. M. El-Baldry, G. Fetih and M. Fathy, Improvement of solubility and dissolution rate of indomethacin by solid dispersions in Gelucire 50/13 and PEG 4000, Saudi Pharm. J. 17 (2009) 219-229; DOI: 10.1016/J.JSPS.2009.08.006.

5. M. Fernandez, I. C. Rodriguez and A. Crezo, Characterization of solid dispersions of piroxicam/polyethylene glycol 4000, Int. J. Pharm. 84 (1992) 197-202; DOI: 10.1016/0378-5173(92)90060-F.

6. D. Horter and J. B. Dressman, Influence of physicochemical properties on dissolution of drugs in the gastrointestinal tract, Adv. Drug Del Rev. 25 (1997) 3-14; DOI: 10.1016/S0169-409X (00) 00130-7.

7. P. B. Myrdal and M. J. Jozwiakowski, Water-Insoluble Drug Formulation, in Alteration of the Solid State of the Drug Substances: Polymorphs, Solvates, and Amorphous Forms, $2^{\text {nd }}$ ed. (Ed. R. Lin), AustarPharma, Edison (NJ), 2008.

8. M. C. Martinez-Oharriz, C. Martýn, M. M. Goni, C. Rodrýguez-Espinosa, A. Zornoza and M. C. Tros-Ilarduya, Influence of polyethylene glycol 4000 on the polymorphic forms of diflunisal, Eur. J. Pharm. Sci. 8 (1999) 127-132; DOI: 10.1016/S0928-0987(99)00006-8.

9. M. Mihalić, H. Hofman, J. Kuftinec, B. Krile, M. Zinic, F. Kajfez and N. Blazevic, Physicochemical and analytical characteristics of piroxicam, Acta Pharm. Jugosl. 32 (1982) 13-20. 
10. K. Srinivasan, K. Sankaranarayanan, S. Thangavelu and P. Ramasamy, Influence of organic solvents on the habit of NMBA (4-nitro-4'-methyl benzylidene aniline) crystals, J. Cryst. Grow. 212 (2000) 246-54; DOI: 10.1016/S0022-0248(00)00300-6.

11. V. Tantishaiyakul, N. Kaewnopparat and S. Ingkatawornwong, Properties of solid dispersion of piroxicam in polyvinylpyrrodine, Int. J. Pharm. Sci. 181 (1999) 143-51; DOI: 10.1016/S0378-5173(96) 04687-X.

12. S. Verheyen, N. Blaton, R. Kinget and G. Van den Mooter, Mechanism of increased dissolution of diazepam and temazepam from polyethylene glycol 6000 solid dispersions, Int. J. Pharm. 249 (2002) 45-58; DOI: 10.1016/S0378-5173(02)00532-X.

13. F. Vrecer and S. Srcic, Investigation of piroxicam polymorphism, Int. J. Pharm. 68 (1990) 35-41; DOI: 10.1016/S0378-5173(03)00057-7.

14. F. Vrečer, M. Vrbinc and A. Meden, Characterisation of piroxicam crystal modifications, Int. J. Pharm. 256 (2003) 3-15; DOI: 10.1016/S0378-5173(03)00057-7.

15. United States Pharmacopoeia 24/National Formulary 19, USP Pharmacopoeial Convention, Rockville (MD) 2000.

$S A \check{Z} E T A K$

\section{Kristalne modifikacije i profil oslobađanja piroksikama}

LIM YEE LYN, HUAN WEN SZE, ADHIYAMAN RAJENDRAN, GORAJANA ADINARAYANA, KAMAL DUA i SANJAY GARG

Piroksikam je nesteroidni protuupalni lijek male topljivosti u vodi koji ima svojstvo polimorfije. Cilj rada bio je priprema polimorfa piroksikama povećane topljivosti i brzine oslobađanja koristeći smjese različitih otapala i PEG 4000, odnosno PVP K30. Fizikokemijska svojstva modificiranih kristalnih oblika piroksikama ispitivana su difrakcijom X-zraka na praškastom uzorku FT-IR spektrofotometrijom i diferencijalnom pretražnom kalorimetrijom. Profili oslobađanja i topljivosti modificiranih kristalnih oblika proučavani su i uspoređivani sa čistim piroksikamom. Metodom uparavanja otapala (metoda I) dobiveni su igličasti i kubični kristali. Polaganom kristalizacijom iz etanola uz dodatak PEG 4000 ili PVP K30 na sobnoj temperaturi (metoda II) dobiveni su kubični kristali. Igličasti kristali dobiveni metodom I poboljšali su oslobađanje, ali ne i topljivost. Kubični kristali dobiveni metodom I imali su poboljšanu topljivost, ali sličan profil oslobađanja kao i netretirani piroksikam. Kubični kristali dobiveni metodom II imali su poboljšani profil oslobađanja, bez značajne promjene $u$ topljivosti. Na temelju XRPD rezultata, modificirani kristali piroksikama dobiveni metodom I iz smjese acetona i benzena bili su kubični, što dobro korelira s FTIR spektrom; modificirani igličasti kristali dobiveni iz smjese etanol/metanol i etanol/aceton imali su lagani pomak FTIR signala što bi se moglo pripisati razlikama $u$ internoj strukturi ili konformacijama.

Ključne riječi: piroksikam, polimorfizam, kristalizacija, polimer, oslobađanje

School of Pharmacy and Health Sciences, International Medical University, Bukit Jalil, Kuala Lumpur Malaysia

AnQual Laboratories, School of Pharmacy, University of Auckland, Auckland, New Zealand 